\title{
Screening of Different Varieties for Resistance to Stem Borer, Chilo partellus (Swinhoe) Infesting Forage Sorghum, Sorghum bicolor (L.) Moench
}

\author{
C. T. Patel*, C. C. Patel and C. B. Varma \\ Department of Entomology, Anand Agricultural University, Anand, Gujarat, India \\ *Corresponding author
}

\section{A B S T R A C T}

\begin{tabular}{l} 
Ke y w o r d s \\
$\begin{array}{l}\text { Sorghum, Chilo } \\
\text { partellus, Fodder, } \\
\text { Physical/ } \\
\text { morphological etc. }\end{array}$ \\
\hline Article Info \\
\hline $\begin{array}{l}\text { Accepted: } \\
\text { 28 January } 2021 \\
\text { Available Online: } \\
\text { 10 February } 2021\end{array}$ \\
\hline
\end{tabular}

\section{Introduction}

Sorghum [Sorghum bicolor (L.) Moench] is one of the important food, feed and fodder crops in the world. It is cultivated widely throughout tropical, subtropical and temperate region of the world. It is used for human consumption especially in rural areas. It has also great potential to supplement fodder resources in India because of its wide adaptation, rapid growth, high green and dry fodder yield with high ratooning and drought tolerance. The crop is grown in about 8.45 million hectares with annual grain production of 7.4 million tons in India. It ranks third next to rice and wheat both in area and production (Anonymous, 2007). Green fodder is the cheapest source of feed for milch, beef and draft animals. Therefore, development of fodder resources of the country becomes a high priority national programme. Insect pests are one of the major limiting factors for low yield of sorghum. In India, nearly $32.1 \%$ of total crop produce was lost due to insect pests (Borad and Mittal, 1983). The sorghum crop is attacked by 150 species of insect pests during its lifespan (Reddy and Davies, 1979). Among different insects, stem borer is most important which causes dead hearts. Use of insecticides for the control of insect pests is 
not advisable on sorghum as a fodder crop due to hazardous effect of insecticidal residues on animals. Host plant resistance plays a major role in reducing the extent of losses in this crop and is compatible with other pest management practices (Sharma, 1993). The use of insect resistant cultivar is an essential component of IPM which offers an economic, stable and ecologically sound approach to minimize the damage caused by the borers. There are many plant characters which are responsible for host plant resistance. The plant structures may influence positively as well as negatively on herbivores and their natural enemies (Krips et al., 1999; Afzal and Bashir, 2007). Hence, it is highly essential to find out varieties which are resistant or tolerant to different insect pests. Therefore, it is required to find out resistant varieties of forage sorghum against stem borer so far as plant protection is concern.

\section{Materials and Methods}

The experiment was carried out under middle Gujarat condition at Main Forage Research Station, Anand Agricultural University, Anand during Kharif 2009-10. The experiment was laid in randomized block design (RBD) with 3 replications with spacing of $30 \mathrm{~cm}$ (drill). The cultural practices except plant protection measures were followed.

\section{Methodology of recording Stem borer infestation}

Twenty five plants were selected randomly from each variety/genotype and plants showing dead hearts were recorded on 23, 30, 37and 44 days after emergence. The percentage of stem borer damaged plants was calculated and data were statistically analyzed by following standard procedure (Steel and Torrie, 1980).

\section{Methodology of recording length of galleries made by Stem borer}

Five plants were selected randomly from each genotype at the time of harvest from the plants having dead hearts. Lengths of galleries were measured and number of larvae/pupae was also counted from the selected plants.

\section{Criteria for categorization of sorghum varieties}

The sorghum cultivars were grouped into four categories based on percentage of dead hearts caused by stem borer. For the purpose, mean value of individual genotype $\left(\bar{x}_{i}\right)$ was compared with mean value of all genotypes $(\bar{X})$ and standard deviation (sd) following the modified scale adopted by Patel et al., (2002).Statistical analysis was carried out by following standard procedure (Steel and Torrie, 1980).Category of resistance were resistant, tolerant, susceptible and highly susceptible and scale for resistances were $\bar{X}_{i}<\bar{x}-s d, \bar{x}_{i}>\bar{x}-\operatorname{sd}<\bar{x}, \bar{x}_{i}>\bar{x}<(\bar{x}+$ sd) and $\bar{X}_{i}>(\bar{X}+s d)<\bar{X}+2$ sd $)$, respectively.

\section{Analysis of biophysical characteristics of sorghum varieties}

\section{Leaf area}

The observations on leaf length and breadth were recorded from 10 randomly selected plants at weekly interval. The leaf length was measured along with midrib.

Breadth was measured at the broadest point of the same leaf using centimetre scale. The leaf length and breadth ratio was calculated. Leaf area was calculated by using formula $\mathrm{LA}=\mathrm{L}$ X B X LAC (Narayan et al., 1985). 


\section{Plant height}

The Plant heights of 10 different plants from each variety/genotype were measured from the soil surface to the apex of the central leaf.

\section{Total number of leaves}

Total numbers of leaves of 10 randomly selected plants from each variety/genotype were counted.

\section{Glossiness of leaf blade}

The glossiness of leaves was recorded by $1-5$ index from 10 randomly selected plants of each variety/genotype.

\section{Seedling vigour}

The plant vigour was recorded by 1-5 index from the 10 randomly selected plants of each variety/genotype.

\section{Results and Discussion}

\section{Screening of different verities against stem borer infesting sorghum}

Categorize various varieties of sorghum into four categories of resistance/susceptibility to stem borer viz., resistant, moderately resistant, susceptible and highly susceptible. The details of categorization are presented in Table-1.

The varieties AFS-28 and SSG-59-3 which recorded less than 69.47 percent dead hearts were found resistant to stem borer. The varieties AFS-26, AFS-30 and AFS-36 recorded more than 69.47 but less than 83.0 percent dead hearts were found moderately resistant. While, AFS-34 variety of sorghum recorded more than 83.0 but less than 96.53 percent dead hearts was found susceptible. AFS-32, MP Chari and COFS-29 varieties of sorghum recorded more than 96.53 but less than 110.06 percent dead hearts were found highly susceptible variety.

Morphological/biophysical characters of different varieties associated with stem borer resistance

The mean percent dead hearts (Table 2) caused by stem borer on 23 days after emergence $\left(4^{\text {th }}\right.$ week of July) revealed that minimum per cent dead hearts were recorded in AFS-28 (44.00) which was at par with AFS-26 (47.00) and AFS-30 (49.00). Whereas, maximum per cent dead hearts were found in MP Chari (87.00) which was at par with COFS-29 (85.00) and AFS-32 (85.00). The per cent dead hearts was found intermediate in SSG-59-3 (52.00) which was at par with AFS-34 (69.00) and AFS-36 (73.00) on 23 days after emergence $\left(4^{\text {th }}\right.$ week of July). The mean percent dead hearts (Table 3 ) on 30 days after emergence $\left(1^{\text {st }}\right.$ week of August) indicated that minimum per cent dead hearts were recorded in AFS-28 (53.00). While, maximum in AFS-32 (95.00) which was at par with COFS-29 (93.00) and MP Chari (92.00). The per cent dead hearts were found intermediate in SSG-59-3 (57.00) which was at par with AFS-26 (59.00), AFS30 (63.00), AFS-34 (80.00) and AFS-36 (81.00) 30 days after emergence $\left(1^{\text {st }}\right.$ week of August).

The mean percent dead hearts (Table 4) caused by stem borer on 37 days after emergence $\left(2^{\text {nd }}\right.$ week of August) were minimum in SSG-59-3 (63.00) which was at par with AFS-28 (64.00), AFS-26 (68.00) and AFS-30 (68.00). Whereas, it was maximum in COFS-29 (100.00) which was at par with MP Chari (100.00) and AFS-32 (99.00). The per cent dead hearts were found intermediate in AFS-34 (81.00) which was at par with AFS$36(83.00)$ on 37 days after emergence $\left(2^{\text {nd }}\right.$ week of August). 
The mean percent dead hearts (Table 5) recorded on 44 days after emergence $\left(3^{\text {rd }}\right.$ week of August) were found equal in AFS-28 (67.00) and SSG-59-3 (67.00) among resistant varieties. In moderately resistant varieties, it was maximum in AFS-36 (81.00) and minimum in AFS-26 (71.00). The per cent dead hearts were 84.00 in susceptible variety AFS-34. In highly susceptible varieties, cent per cent dead hearts were found in AFS-32, MP Chari and COFS-29.

\section{Plant height}

The data on plant height $(\mathrm{cm})$ revealed that among resistant varieties, the maximum and minimum plant height was observed in the varieties AFS-28 (142.43) and SSG-59-3 (135.23), respectively. In moderately resistant varieties, it was maximum in AFS-30 (152.10) and minimum in AFS-36 (125.73). The plant height was $133.20 \mathrm{~cm}$ in susceptible variety AFS-34. In highly susceptible varieties, the maximum plant height was noted in AFS-32 (163.10) and minimum in COFS-29 (136.00).Kumar and Bhatnagar (1962) reported that less heighted plants showed resistance to stem borer. Whereas, Kundu and Jotwani (1977) and Khurana (1980) reported that medium plant height was responsible for resistance to stem borer, $C$. partellus. Similarly, Patel and Sukhani (1990) reported with increase in the plant height the resistance increased to a certain extent and thus it can be characterised to be associated with the resistance.

\section{Leaf length}

The data on leaf length $(\mathrm{cm})$ revealed that among resistant varieties, the maximum and minimum leaf length was found in the varieties SSG-59-3 (76.60) and AFS-28 (75.70), respectively. In moderately resistant varieties, it was maximum in AFS-30 (82.17) and minimum in AFS-36 (77.37). The leaf length was $77.13 \mathrm{~cm}$ in susceptible variety AFS-34. In highly susceptible varieties, the maximum leaf length was noted in AFS-32 (81.80) and minimum in MP Chari (67.00).Kumar and Bhatnagar (1962) reported that leaves of plant were less in length in varieties resistant to stem borer in sorghum. Afzal et al., (2009) also concluded similar causes of resistance i.e. lower leaf length higher the resistance to $C$. partellus in maize.

\section{Leaf width}

The data on leaf width $(\mathrm{cm})$ revealed that among resistant varieties, the maximum and minimum leaf width was noted in the varieties AFS-28 (4.97) and SSG-59-3 (4.67), respectively. In moderately resistant varieties, it was maximum in AFS-36 (5.00) and minimum in AFS-30 (4.60). The leaf width was $4.73 \mathrm{~cm}$ in susceptible variety AFS-34. In highly susceptible varieties, the maximum leaf width was observed in AFS-32 (4.70) and minimum in COFS-29 (4.00). Bothe (1979) observed that tolerant varieties had narrower leaves than susceptible ones. Singh and Jotwani (1980) reported that narrow leaves found to be factors contributing to resistance to the pest. Also, Afzal et al., (2009) also concluded similar causes of resistance i.e. narrower the leaves higher the resistance to $C$. partellus in maize.

\section{Leaf area}

The data on leaf area $\left(\mathrm{cm}^{2}\right)$ revealed that among resistant varieties, the maximum and minimum leaf area was noted in the varieties AFS-28 (267.09) and SSG-59-3 (254.00), respectively. In moderately resistant varieties, it was maximum in AFS-36 (274.45) and minimum in AFS-30 (268.16). The leaf area was $259.27 \mathrm{~cm}$ in susceptible variety AFS-34. In highly susceptible varieties, the maximum leaf width was observed in AFS-32 (273.46) and minimum in MP Chari (193.61).Kumar et 
al., (2000) as well as Afzal et al., (2009) revealed that the varieties with narrow leaves (length greater than width) were responsible for resistance against the shoot fly.

\section{Numbers of leaves/plant}

The data on number of leaves/plant revealed that among resistant varieties, the maximum and minimum number of leaves/plant were noted in the varieties AFS-28 (9.67) and SSG59-3 (8.67), respectively. In moderately resistant varieties, it was maximum in AFS-26 (9.67) and minimum in AFS-36 (8.67). The number of leaves/plant was 8.33 in susceptible variety AFS-34. In highly susceptible varieties, the maximum number of leaves/plant were observed in COFS-29 (7.33) and minimum in MP Chari (6.67).The more number of leaves per plant less will be the pest incidence (Rao et al., 2000).

\section{Leaf glossiness}

The data on score of leaf glossiness revealed that among resistant varieties, the maximum and minimum score of leaf glossiness was noted in the varieties AFS-28 (5.00) and SSG59-3 (3.33), respectively. In moderately resistant varieties, it was maximum in both AFS-26 and AFS-30 (4.33) and minimum in AFS-36 (4.00). The score of leaf glossiness was 4.00 in susceptible variety AFS-34. In highly susceptible varieties, the maximum score of leaf glossiness was observed in COFS-29 (3.33) and minimum in MP Chari (2.67). The present findings also fall in the same line with results of Kamatar and Salimath (2003) as well as Sharma et al., (2007) who reported that high glossiness of leaves confer resistance to sorghum shoot fly.

\section{Plant vigour}

The data on score of plant vigour revealed that among resistant varieties, the equal score of plant vigour was found in both varieties AFS-28 and SSG-59-3 (3.33). In moderately resistant varieties, it was maximum in AFS-30 (3.67) and minimum in AFS-26 (3.00). The score of plant vigour was 3.33 in susceptible variety AFS-34. In highly susceptible varieties, the maximum score of plant vigour was observed in COFS-29 (4.33) and minimum in AFS-32 (2.67).Kamatar and Salimath (2003) indicated that more plant vigour was responsible for imparting resistance to sorghum shoot fly.

Table.1 Categorization of different varieties of sorghum for their resistance/susceptibility to $C$. partellus based on percentage of dead hearts

\begin{tabular}{|c|c|c|c|}
\hline Category of resistance & Scale & \multicolumn{2}{|c|}{ Varieties $\left(\overline{X_{i}}\right)$} \\
\hline Resistant & $\overline{x_{i}}<69.47$ & $\begin{array}{l}\text { AFS-28 } \\
\text { SSG-59-3 }\end{array}$ & $\begin{array}{l}(67.0) \\
(67.0)\end{array}$ \\
\hline Moderately Resistant & $\overline{x_{i}}>69.47<83.0$ & $\begin{array}{l}\text { AFS-26 } \\
\text { AFS-30 } \\
\text { AFS-36 }\end{array}$ & $\begin{array}{l}(71.0) \\
(73.0) \\
(81.0)\end{array}$ \\
\hline Susceptible & $\overline{x_{i}}>83.0<96.53$ & AFS-34 & $(84.0)$ \\
\hline Highly susceptible & $\overline{X_{i}}>96.53<110.06$ & $\begin{array}{l}\text { AFS-32 } \\
\text { MP Chari } \\
\text { COFS-29 }\end{array}$ & $\begin{array}{l}(100.0) \\
(100.0) \\
(100.0)\end{array}$ \\
\hline
\end{tabular}

Based on percentage of dead hearts: $\bar{x}=83.0$ and $s d=13.53$ 
Table.2 Stem borer incidence and plant characters of 23 days old sorghum Plants

\begin{tabular}{|c|c|c|c|c|c|c|c|c|c|}
\hline Sr. No. & Varieties & $\begin{array}{c}\text { Mean Percentage } \\
\text { of dead hearts by } \\
\text { C. partellus }\end{array}$ & $\begin{array}{c}\text { Plant height } \\
\text { (cm) }\end{array}$ & $\begin{array}{l}\text { Leaf length } \\
(\mathrm{cm})\end{array}$ & $\begin{array}{l}\text { Leaf width } \\
\text { (cm) }\end{array}$ & $\begin{array}{c}\text { Leaf area } \\
(\mathrm{cm} 2)\end{array}$ & $\begin{array}{l}\text { Number of } \\
\text { leaves/plant }\end{array}$ & $\begin{array}{c}\text { Leaf } \\
\text { Glossiness }\end{array}$ & $\begin{array}{l}\text { Plant } \\
\text { Vigour }\end{array}$ \\
\hline 1 & AFS-28 & 44 & 47.50 & 48.17 & 3.40 & 116.09 & 6.67 & 3.33 & 3.33 \\
\hline 2 & SSG-59-3 & 52 & 41.87 & 45.83 & 3.07 & 99.89 & 6.33 & 2.33 & 2.33 \\
\hline 3 & AFS-26 & 47 & 44.73 & 46.17 & 3.13 & 102.62 & 5.67 & 4.00 & 4.00 \\
\hline 4 & AFS-30 & 49 & 48.43 & 53.20 & 3.70 & 140.27 & 6.33 & 2.33 & 2.33 \\
\hline 5 & AFS-36 & 73 & 41.23 & 44.93 & 3.70 & 117.87 & 6.00 & 3.67 & 3.67 \\
\hline 6 & AFS-34 & 69 & 46.40 & 52.27 & 3.10 & 114.93 & 6.67 & 1.67 & 1.67 \\
\hline 7 & AFS-32 & 85 & 40.97 & 42.17 & 3.13 & 93.94 & 4.67 & 1.33 & 1.33 \\
\hline 8 & MP Chari & 87 & 39.10 & 40.90 & 2.83 & 82.27 & 4.67 & 2.00 & 2.00 \\
\hline \multirow[t]{4}{*}{9} & COFS-29 & 85 & 39.40 & 43.17 & 2.80 & 85.77 & 5.00 & 4.67 & 4.67 \\
\hline & S. Em \pm & 2.52 & 0.79 & 0.89 & 0.18 & 6.60 & 0.29 & 0.44 & 0.44 \\
\hline & C. D. at $5 \%$ & 7.57 & 2.36 & 2.67 & 0.54 & 19.80 & 0.87 & 1.32 & 1.32 \\
\hline & CV \% & 6.65 & 3.13 & 3.33 & 9.73 & 10.81 & 8.65 & 27.03 & 27.03 \\
\hline
\end{tabular}

Table.3 Stem borer incidence and plant characters of 30 days old sorghum Plants

\begin{tabular}{|c|c|c|c|c|c|c|c|c|c|}
\hline Sr. No. & Varieties & $\begin{array}{c}\text { Mean } \\
\text { Percentage of } \\
\text { dead hearts by } \\
\text { C. partellus }\end{array}$ & $\begin{array}{l}\text { Plant height } \\
\quad(\mathrm{cm})\end{array}$ & $\begin{array}{l}\text { Leaf length } \\
\quad(\mathrm{cm})\end{array}$ & $\begin{array}{l}\text { Leaf width } \\
\quad(\mathrm{cm})\end{array}$ & $\begin{array}{l}\text { Leaf area } \\
(\mathrm{cm} 2)\end{array}$ & $\begin{array}{l}\text { Number of } \\
\text { leaves/plant }\end{array}$ & $\begin{array}{c}\text { Leaf } \\
\text { Glossiness }\end{array}$ & $\begin{array}{l}\text { Plant } \\
\text { Vigour }\end{array}$ \\
\hline 1 & AFS-28 & 53 & 73.90 & 57.97 & 3.87 & 158.89 & 6.67 & 3.67 & 3.33 \\
\hline 2 & SSG-59-3 & 57 & 64.13 & 63.47 & 3.40 & 153.22 & 6.33 & 3.33 & 2.33 \\
\hline 3 & AFS-26 & 59 & 71.63 & 57.83 & 3.53 & 145.28 & 6.67 & 4.33 & 4.33 \\
\hline 4 & AFS-30 & 63 & 70.87 & 67.33 & 4.13 & 197.78 & 6.33 & 2.67 & 2.67 \\
\hline 5 & AFS-36 & 81 & 61.17 & 66.47 & 4.13 & 194.82 & 6.00 & 3.33 & 3.33 \\
\hline 6 & AFS-34 & 80 & 66.10 & 63.13 & 3.40 & 152.34 & 6.67 & 2.33 & 2.33 \\
\hline 7 & AFS-32 & 95 & 63.20 & 69.17 & 3.50 & 172.11 & 4.67 & 2.00 & 1.67 \\
\hline 8 & MP Chari & 92 & 57.10 & 54.47 & 3.20 & 124.00 & 4.67 & 1.67 & 2.33 \\
\hline \multirow[t]{4}{*}{9} & COFS-29 & 93 & 44.63 & 65.43 & 3.40 & 157.67 & 5.00 & 4.00 & 4.33 \\
\hline & S. Em \pm & 3.11 & 0.93 & 0.52 & 0.18 & 8.76 & 0.29 & 0.41 & 0.43 \\
\hline & C. D. at $5 \%$ & 3.33 & 2.80 & 1.56 & 0.54 & 26.26 & 0.87 & 1.24 & 1.30 \\
\hline & CV \% & 7.20 & 2.54 & 1.44 & 9.73 & 9.38 & 8.49 & 23.50 & 25.36 \\
\hline
\end{tabular}


Table.4 Stem borer incidence and plant characters of 37 days old sorghum Plants

\begin{tabular}{|c|c|c|c|c|c|c|c|c|c|}
\hline $\begin{array}{l}\text { Sr. } \\
\text { No. }\end{array}$ & Varieties & $\begin{array}{c}\text { Mean } \\
\text { Percentage of } \\
\text { dead hearts by } \\
\text { C. partellus }\end{array}$ & $\begin{array}{l}\text { Plant } \\
\text { height } \\
(\mathrm{cm})\end{array}$ & $\begin{array}{l}\text { Leaf } \\
\text { length } \\
(\mathrm{cm})\end{array}$ & $\begin{array}{l}\text { Leaf width } \\
\text { (cm) }\end{array}$ & $\begin{array}{l}\text { Leaf area } \\
\quad(\mathrm{cm} 2)\end{array}$ & $\begin{array}{l}\text { Number of } \\
\text { leaves/plant }\end{array}$ & $\begin{array}{c}\text { Leaf } \\
\text { Glossines } \\
\text { s }\end{array}$ & $\begin{array}{c}\text { Plant } \\
\text { Vigour }\end{array}$ \\
\hline 1 & AFS-28 & 64 & 119.30 & 68.50 & 4.77 & 232.29 & 8.67 & 4.33 & 3.00 \\
\hline 2 & SSG-59-3 & 63 & 108.93 & 73.70 & 4.13 & 216.37 & 7.33 & 3.67 & 2.67 \\
\hline 3 & AFS-26 & 68 & 93.27 & 73.27 & 4.27 & 221.78 & 8.33 & 4.67 & 3.67 \\
\hline 4 & AFS-30 & 68 & 105.17 & 77.33 & 4.43 & 243.36 & 7.67 & 3.33 & 3.33 \\
\hline 5 & AFS-36 & 83 & 97.10 & 72.27 & 4.83 & 247.86 & 6.67 & 3.67 & 3.00 \\
\hline 6 & AFS-34 & 81 & 102.67 & 72.17 & 4.13 & 212.01 & 7.33 & 3.33 & 2.67 \\
\hline 7 & AFS-32 & 99 & 131.83 & 76.60 & 4.07 & 221.51 & 5.67 & 2.33 & 2.33 \\
\hline 8 & MP Chari & 100 & 94.30 & 63.17 & 3.67 & 164.54 & 5.67 & 2.33 & 2.67 \\
\hline \multirow[t]{4}{*}{9} & COFS-29 & 100 & 89.57 & 70.93 & 3.67 & 184.67 & 6.33 & 3.67 & 4.67 \\
\hline & S. Em \pm & 2.53 & 1.76 & 1.16 & 0.14 & 7.08 & 0.34 & 0.39 & 0.31 \\
\hline & C. D. at $5 \%$ & 7.60 & 5.28 & 3.47 & 0.42 & 21.22 & 1.03 & 1.18 & 0.93 \\
\hline & $\mathrm{CV} \%$ & 5.45 & 2.91 & 2.78 & 5.72 & 5.67 & 8.44 & 19.64 & 17.36 \\
\hline
\end{tabular}


Table.5 Stem borer incidence and plant characters of 44 days old sorghum Plants

\begin{tabular}{|c|c|c|c|c|c|c|c|c|c|}
\hline Sr. No. & Varieties & $\begin{array}{c}\text { Mean Percentage } \\
\text { of dead hearts } \\
\text { by } C \text {. partellus }\end{array}$ & $\begin{array}{c}\text { Plant height } \\
\text { (cm) }\end{array}$ & $\begin{array}{l}\text { Leaf length } \\
(\mathrm{cm})\end{array}$ & $\begin{array}{c}\text { Leaf width } \\
\text { (cm) }\end{array}$ & $\begin{array}{c}\text { Leaf area } \\
\quad(\mathrm{cm} 2)\end{array}$ & $\begin{array}{c}\text { Number of } \\
\text { leaves/plan } \\
t\end{array}$ & $\begin{array}{c}\text { Leaf } \\
\text { Glossiness }\end{array}$ & $\begin{array}{l}\text { Plant } \\
\text { Vigour }\end{array}$ \\
\hline \multicolumn{10}{|c|}{ Resistant varieties } \\
\hline 1 & AFS-28 & 67 & 142.43 & 75.70 & 4.97 & 267.09 & 9.67 & 5.00 & 3.33 \\
\hline 2 & SSG-59-3 & 67 & 135.23 & 76.60 & 4.67 & 254.00 & 8.67 & 3.33 & 3.33 \\
\hline \multicolumn{10}{|c|}{ Moderately resistant varieties } \\
\hline 3 & AFS-26 & 71 & 128.77 & 79.57 & 4.77 & 269.37 & 9.67 & 4.33 & 3.00 \\
\hline 4 & AFS-30 & 73 & 152.10 & 82.17 & 4.60 & 268.16 & 9.00 & 4.33 & 3.67 \\
\hline 5 & AFS-36 & 81 & 125.73 & 77.37 & 5.00 & 274.45 & 8.67 & 4.00 & 3.33 \\
\hline \multicolumn{10}{|c|}{ Susceptible varieties } \\
\hline 6 & AFS-34 & 84 & 133.20 & 77.13 & 4.73 & 259.27 & 8.33 & 4.00 & 3.33 \\
\hline \multicolumn{10}{|c|}{ Highly Susceptible varieties } \\
\hline 7 & AFS-32 & 100 & 163.10 & 81.80 & 4.70 & 273.46 & 7.00 & 3.00 & 2.67 \\
\hline 8 & MP Chari & 100 & 144.17 & 67.00 & 4.07 & 193.61 & 6.67 & 2.67 & 3.33 \\
\hline \multirow[t]{4}{*}{9} & COFS-29 & 100 & 136.00 & 75.80 & 4.00 & 215.62 & 7.33 & 3.33 & 4.33 \\
\hline & S. Em \pm & 2.17 & 1.84 & 0.88 & 0.14 & 8.32 & 0.42 & 0.33 & 0.54 \\
\hline & C. D. at $5 \%$ & 6.51 & 5.53 & 2.62 & 0.43 & 24.95 & 1.26 & 0.98 & - \\
\hline & $\mathrm{CV} \%$ & 4.56 & 2.28 & 1.97 & 5.42 & 5.70 & 8.84 & 14.96 & 27.68 \\
\hline
\end{tabular}

Table.6 Correlation between different Morphological parameters and dead hearts caused by C. partellus

\begin{tabular}{|c|c|}
\hline Morphological/Biophysical constituents & Dead hearts caused by C. partellus \\
\hline Plant height & 0.339 \\
\hline Leaf length & -0.336 \\
\hline Leaf width & -0.672 \\
\hline Leaf area & -0.596 \\
\hline Number of leaves/Plant & $-0.919 * *$ \\
\hline Leaf glossiness & $-0.759 *$ \\
\hline Plant vigour & 0.126 \\
\hline Tillers/Plant & 0.464 \\
\hline $\mathbf{r}_{\mathbf{0 . 0 5}}$ ( 7df) & 0.754 \\
$\mathbf{r}_{\mathbf{0 . 0 1}}$ ( 7 df) & 0.875 \\
\hline$*$ Significant (At 5 \%), ** Significant (At 1\%)
\end{tabular}


Int.J.Curr.Microbiol.App.Sci (2021) 10(02): 3508-3519

Table.7 Stem borer incidence, plant characters and yield of 44 days old sorghum Plants

\begin{tabular}{|c|c|c|c|c|c|c|c|c|}
\hline \multirow[b]{2}{*}{ Sr. No. } & \multirow[b]{2}{*}{ Varieties } & \multirow{2}{*}{$\begin{array}{l}\text { Mean Percentage of } \\
\text { dead hearts by } C \text {. } \\
\text { partellus }\end{array}$} & \multirow[b]{2}{*}{ Tillers/Plant } & \multirow{2}{*}{$\begin{array}{l}\text { Stem thickness } \\
(\mathrm{cm})\end{array}$} & \multicolumn{2}{|c|}{ Yield in $\mathrm{q} / \mathrm{ha}$} & \multicolumn{2}{|c|}{ Yield in $\mathrm{q} / \mathrm{ha} /$ day } \\
\hline & & & & & Green fodder & Dry matter & Green fodder & Dry matter \\
\hline \multicolumn{9}{|c|}{ Resistant varieties } \\
\hline 1 & AFS-28 & 67 & 1.4 & 0.63 & 488 & 104.9 & 3.94 & 0.85 \\
\hline 2 & SSG-59-3 & 67 & 2.0 & 0.56 & 587 & 120.5 & 4.73 & 0.97 \\
\hline \multicolumn{9}{|c|}{ Moderately resistant varieties } \\
\hline 3 & AFS-26 & 71 & 1.8 & 0.54 & 547 & 133.1 & 4.41 & 1.07 \\
\hline 4 & AFS-30 & 73 & 1.7 & 0.75 & 625 & 139.4 & 5.04 & 1.12 \\
\hline 5 & AFS-36 & 81 & 1.7 & 0.69 & 559 & 139.9 & 4.51 & 1.13 \\
\hline \multicolumn{9}{|c|}{ Susceptible varieties } \\
\hline 6 & AFS-34 & 84 & 1.9 & 0.60 & 492 & 114.2 & 3.97 & 0.92 \\
\hline \multicolumn{9}{|c|}{ Highly Susceptible varieties } \\
\hline 7 & AFS-32 & 100 & 1.7 & 0.70 & 503 & 110.5 & 4.06 & 0.89 \\
\hline 8 & MP Chari & 100 & 2.0 & 0.57 & 434 & 119.3 & 3.50 & 0.96 \\
\hline \multirow[t]{4}{*}{9} & COFS-29 & 100 & 2.1 & 0.53 & 733 & 176.6 & 5.91 & 1.42 \\
\hline & S. Em. + & 2.17 & - & - & 35.9 & 8.6 & - & - \\
\hline & C.D. at $0.5 \%$ & 6.51 & - & - & 107.6 & 25.7 & - & - \\
\hline & C.V.\% & 4.56 & - & - & 11.2 & 11.5 & - & - \\
\hline
\end{tabular}




\section{Correlation coefficient}

The correlation between infestation level and morphological characters presented in Table 6 and it was not significant except number of leaves/plant and score of leaf glossiness. A negative correlation between percent dead heart caused by stem borer and number of leaves/plant $\left[\mathrm{r}_{0.05}(7 \mathrm{df})=-0.919\right]$ and score of leaf glossiness $\left[\mathrm{r}_{0.01}(7 \mathrm{df})=-0.759\right]$ were negative indicating that with an increase in these factors the activity of pest was decreased. Similar findings were reported by Sharma et al., (2007) for leaf glossiness and are agreement with the present results.

\section{Tillers per plant}

The data presented in Table 7 on tillers per plant revealed that among resistant varieties, the maximum and minimum tillers per plant were observed in the varieties SSG-59-3 (2.0) and AFS-28 (1.4), respectively. In moderately resistant varieties, it was maximum in AFS-26 (1.8) and minimum in both AFS-30 and AFS36 (1.7). The tillers per plant were 1.9 in susceptible variety AFS-34. In highly susceptible varieties, the maximum tillers per plant were found in COFS-29 (2.1) and minimum in AFS-32 (1.7).

\section{Stem thickness}

The data presented in Table 7 on stem thickness $(\mathrm{cm})$ revealed that among resistant varieties, the maximum and minimum stem thickness was noted in the varieties AFS-28 (0.63) and SSG-59-3 (0.56), respectively. In moderately resistant varieties, it was maximum in AFS-30 (0.75) and minimum in AFS-26 (0.54). The stem thickness was 0.60 $\mathrm{cm}$ in susceptible variety AFS-34. In highly susceptible varieties, the maximum stem thickness was found in AFS-32 (0.70) and minimum in COFS-29 (0.53). Khurana (1980) reported that stem thickness was responsible for imparting resistance to $C$. partellus. Present results are in agreement with the reports of Afzal et al., (2009) who concluded similar causes of resistance i.e. medium thinner to thin stem showed resistance to $C$. partellus in maize.

\section{Green fodder yield}

The data presented in Table 7 on green fodder yield (q/ha) revealed that among resistant varieties, the maximum and minimum green fodder yield was noted in the varieties SSG59-3 (587.0) and AFS-28 (488.0), respectively. In moderately resistant varieties, it was maximum in AFS-30 (625.0) and minimum in AFS-26 (547.0). The green fodder yield was $492.0 \mathrm{q} / \mathrm{ha}$ in susceptible variety AFS-34. In highly susceptible varieties, the maximum green fodder yield was observed in COFS-29 (733.0) and minimum in MP Chari (434.0).

\section{Dry matter yield}

The data presented in Table 7 on dry matter yield (q/ha) revealed that maximum dry matter yield was found in SSG-59-3 (120.5) and minimum in AFS-28 (104.9) among resistant varieties, whereas in moderately resistant varieties, it was maximum in AFS-36 (139.9) and minimum in AFS-26 (133.1). The dry matter yield was $114.2 \mathrm{q} / \mathrm{ha}$ in susceptible variety AFS-34. In highly susceptible varieties, the maximum dry matter yield observed in COFS-29 (176.6) and minimum in AFS-32 (110.5).

\section{Green fodder yield}

The data presented in Table 7 on green fodder yield/day (q/ha) revealed that among resistant varieties, the maximum and minimum green fodder yield/day was found in the varieties SSG-59-3 (4.73) and AFS-28 (3.94), respectively. In moderately resistant varieties, 
it was maximum in AFS-30 (5.04) and minimum in AFS-26 (4.41). The green fodder yield/day was $3.97 \mathrm{q} / \mathrm{ha}$ in susceptible variety AFS-34. In highly susceptible varieties, the maximum green fodder yield/day was observed in COFS-29 (5.91) and minimum in MP Chari (3.50).

It can be concluded that different sorghum verities behaved differently against stem borer, $C$. partellus. Lesser than 69.47 per cent dead hearts were found in the varieties of AFS-28 and SSG-59-3 showing resistance. While, more than 69.47 but less than 83.0 per cent dead hearts were observed in the varieties of AFS-26, AFS-30 and AFS-36 recording moderate resistance. Number of leaves/plant and score of leaf glossiness were observed to have a negative correlation between percent dead hearts caused by stem borer and indicating that with increase in these factors the infestation of pest was decreased. The information about these morphological characters also will aid the evaluation of breeding lines so as to further increase (in cultivated crops) the levels of resistance to stem borer.

\section{Acknowledgement}

We are grateful to Director of Research and Dean PG Studies, Principal and Dean (Agri.), BACA and Professor and Head, Department of Entomology for providing facilities for this research work.

\section{References}

Afzal, M. and Bashir, M. H (2007). Influence of certain leaf characters of some summer vegetables with incidence of predatory mites of the family Cunaxidae. Pak. J. Bot., 39(1):205-209.

Afzal, M., Nazir, Z, Bashir, M. H and Khan, B. S. (2009). Analysis of host plant resistance in some genotypes of maize against Chilo partellus (Swinhoe) (Pyralidae: Lepidoptera). Pak. J. Bot., 41 (1): 421-428.

Anonymous (2007). Agricultural Statistic at a glance. Directorate of Economics and Statistics, Dept. of Agril. And Cooperation, Ministry of Agriculture, Govt. of India. (http:// www.agricoop.nic.in/Agristatistics, htm)

Borad, P. K. and Mittal, R. S. (1983). Assessment of losses caused by pest complex to sorghum hybrid, CSH 5. In: B.H. Krishnamurthy Rao and K.S.R.K. Murthy (Eds.), Crop losses due to insect pests, special issue of Ind. J. Ent., pp 271-278. IARI, New Delhi.

Bothe, N. N. (1979). Screening of some sorghum lines for resistance to shoot fly, Atherigona soccata (Rondani). $M$. Sc. (Agri.) Thesis submitted to $M P K V$, Rahuri.

Kamatar, M. Y. and Salimath, P. M. (2003). Morphological traits of sorghum associated with resistance to shoot fly, Atherigona soccata Rondani. Ind. J. Plant Prot., 31 (1):73- 77.

Khurana, A. D. (1980). Studies on resistance in forage sorghum to Chilo partellus (Swinhoe) (Lepidoptera: Crambidae) and Atherigona soccata (Rondani) (Diptera: Muscidae). Thesisabstracts, Haryana Agric. Univ., Hissar. pp. 190192.

Krips, O. E., Kleijn, P. W., Willems, P. E. L., Gols, G. J. Z. and Dicke, M. (1999). Leaf hairs influence searching efficiency and predation rate of the predatory mite Phytoseiulus persimilis (Acari: Phytoseiidae). Exp. and Appl. Aca., 23(2):119-131.

Kumar, K. and Bhatnagar, M. P. (1962). Studies on varietal resistance to sorghum stem borer (Chilo zonellus). Ind. J. Agric. Sci., 32: 208-218.

Kumar, V. K., Reddy, K. D., Rao, M. S. and 
Singh, B. U. (2000). Interactive mechanisms of resistance to shoot fly Atherigona soccata with seedling characteristics in sorghum. Ind. J. Ent., 62(1): 69-81.

Kundu, G. G. and Jotwani, M. G. (1977). 477 - A highly promising stem borer resistant line of sorghum. Entomologists' Newsletter, 7 (1): 2- 7.

Narayan, A., Subba Rao, I. V., Ashokarani Y. (1985). Plant physiology Laboratory Manual, Dept. of Plant Physiology, Andhra Pradesh Agricultural University, Bapatla. pp. 18-25.

Patel, G. M. and Sukhani, T. R. (1990). Some biophysical plant characters associated with stem borer resistance in sorghum genotypes. Ind. J. Ent., 52(3): 452-455.

Patel I. S., Prajapati, B. G., Patel, G. M. and Pathak A. R. (2002). Response of castor genotypes to castor semilooper, Achaea janata Fab. J. Oilseeds Res., 19 (1): 153.

Patel I. S., Prajapati, B. G., Patel, G. M. and Pathak A. R. (2002). Response of castor genotypes to castor semilooper, Achaea janata Fab. J. Oilseeds Res., 19 (1): 153.

Rao, S. S., Muhammad, B. and Sahib, K. H. (2000). Correlation studies between the plant characters and shoot fly resistance in sorghum. Crop Res., 19 (2):366-367.

Reddy, K.S. and Davis, J. C. (1979). Pest of sorghum and pear millet and their parasites and predators recorded at ICRISAT Centre, India up to Aug 1979, Cereal entomology report progress no. 2 Pondechery, Andhra Pradesh EO 234 India. ICRISAT. pp. 23.

Sharma, H. C. 1993. Host plant resistance to insects in sorghum and its role in integrated pest management. Crop Protection, 12: 11-34.

Sharma, H. C., Dhillon, M. K., Pampapathy, G. and Reddy B. V. S. (2007). Inheritance of resistance to spotted stem borer, Chilo partellus, in sorghum, Sorghum bicolor. Euphytica, 156:117128.

Singh, S. P. and Jotwani, M. G. (1980). Mechanism of resistance in sorghum to shoot fly. IV. Role of morphological characters of seedlings. Ind. J. Ent.,42 (4):806-808.

Steel, R. G. P and Torrie, J. H. (1980). Principles and procedures of statistics A bio-metrical approach, second edi., McGraw Hill Kogakush Ltd., New Delhi. pp. 137 - 139.

\section{How to cite this article:}

Patel, C. T., C. C. Patel and Varma, C. B. 2021. Screening of Different Varieties for Resistance to Stem Borer, Chilo partellus (Swinhoe) Infesting Forage Sorghum, Sorghum bicolor (L.) Moench. Int.J.Curr.Microbiol.App.Sci. 10(02): 3508-3519. doi: https://doi.org/10.20546/ijcmas.2021.1002.386 